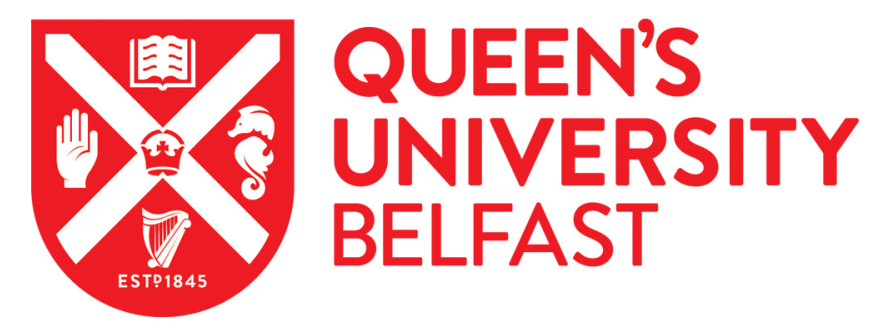

\title{
The rebirth of dependence- offering an alternative understanding of the financial crisis
}

Hackett, C. (2014). The rebirth of dependence- offering an alternative understanding of the financial crisis. International Journal of Law and Management, 56(2), 121-135. https://doi.org/10.1108/IJLMA-12-2012-0041

\section{Published in:}

International Journal of Law and Management

\section{Document Version:}

Peer reviewed version

\section{Queen's University Belfast - Research Portal:}

Link to publication record in Queen's University Belfast Research Portal

\section{Publisher rights}

This article is copyright 2014 Emerald Group Publishing and permission has been granted for this version to appear here. Emerald does not grant permission for this article to be further copied/distributed or hosted elsewhere without the express permission from Emerald Group Publishing Limited. See more at: http://www.emeraldgrouppublishing.com/authors/writing/author_rights.htm\#sthash.QKN24jcS.dpuf

\section{General rights}

Copyright for the publications made accessible via the Queen's University Belfast Research Portal is retained by the author(s) and / or other copyright owners and it is a condition of accessing these publications that users recognise and abide by the legal requirements associated with these rights.

Take down policy

The Research Portal is Queen's institutional repository that provides access to Queen's research output. Every effort has been made to ensure that content in the Research Portal does not infringe any person's rights, or applicable UK laws. If you discover content in the Research Portal that you believe breaches copyright or violates any law, please contact openaccess@qub.ac.uk. 


\title{
The rebirth of dependence - offering an alternative understanding of financial crisis
}

\author{
Ciara Hackett \\ School of Law, Queen's University Belfast, UK
}

\begin{abstract}
Purpose: The recent financial crisis has prompted a re-evaluation of the global market system and the manner in which this system is regulated. This article aims to contribute to this re-evaluation through using a Marxist inspired theory of development, dependency, to understand relationships within the global market.
\end{abstract}

Design/Methodology/Approach: This article draws on a dependency theory as an alternative means of understanding global relationships. It builds on the literature on dependency theory before modifying this to encapsulate technological developments and trends in the global market.

Findings: As illustrated throughout this article, re-evaluating the global market and the relationships that underpin it, through an alternative theory, highlights how fragile markets and associated relationships are. Increasingly, nation states are becoming irrelevant. This in itself presents a problem as, whereas the main actors in the global market today are "above" inter-state relations, the organs that regulate their behaviour still are grounded in inter-state rhetoric. The relationship between development and underdevelopment will remain. It is a product of capitalism.

Research Limitations/implications: The financial crisis has propagated a wealth of interest in the relationships between states, between MNCs and between MNC and state. Using this broad theory of modified dependency, it can now be applied to a range of different relationships. Given the timing of this article, and, in the wake of financial crisis, there is the opportunity to raise awareness of these ingrained issues and initiate discussions at national, regional and international levels to alleviate some of the conditions of dependence.

Practical implications: Regardless of the work of national governments and NGOs to instigate development in lesser-developed regions through policy and regulations, unless there is a conscientious commitment from MNCs operating in that region to contribute to development, the result will be the development of underdevelopment and the underdevelopment of development. CSR can help alleviate the conditions of the dependence on capital generated by MNCs but this is not a solution to an ingrained problem, a symptom of capitalism.

Originality/Value: This article introduces a modified theory of dependency for the first time. It applies the theory to the financial crisis and to the continent of Africa. It considers the role that CSR can play in alleviating the conditions of dependence.

Keywords: Financial Crisis, Dependency, Multi-National Organisations, Underdevelopment

Paper Type: Concept Paper 


\section{Introduction}

In recent years some banks have failed, and, in their demise, have annihilated markets, toppled governments and questioned national governance and regulatory infrastructures' capacity to monitor banking and big business. Much has been written on the causes of financial crises and the challenges for capitalism going forward. This article considers how the capitalist system was and is understood. Using a proposed alternative framework of assessment, it notes that this crisis was inevitable.

This article looks at the dependency theory of development. Dependency emerged in the 1970s, largely abandoned by the mid-1980s. It remains relevant today and, by expanding and modifying the theory for international application, the theory experiences rejuvenation. Increased globalisation, together with the most recent financial crisis, has facilitated a reimagining of dependency, an alternative means to view the global system.

\section{The Transnational Capitalist Class (TCC)}

"One channel through which exposure to financial globalisation may carry a downside is increased vulnerability to financial crisis”(Hong and Wei, 2011).

Bursting property bubbles, subprime mortgage crises, IMF and EU bailouts and the promise of austerity suggest that vulnerability to financial crisis has not only increased, but has been realised ${ }^{1}$. Globalisation, despite benefits to consumer and trader, has made the market economy more susceptible to problems, and highlighted the inadequacies of such relationships' infrastructure. It has illustrated the need to pursue an alternative framework of interpreting the system, to understand the vulnerability

\footnotetext{
1 The collapse of the sub-prime mortgage industry in the US and the resultant property crash facilitated the financial crisis. The impact of this and associated property bubbles triggered worldwide bailouts the consequences of which are still been felt via austerity policies. Within Europe, Greece has become a cautionary tale with $€ 44$ bn being added in November 2012 to the already huge $€ 240$ billion loan. In return for this bailout, the EU and IMF have tasked the Greek government with implementing a series of draconian austerity measures met with much resistance in the country. However, Krugman and Keynes believe that austerity in times of depression/recession does not work. Bailouts have also occurred in Iceland, Ireland, Cyprus, Spain, Portugal, Hungary, Ukraine and Seychelles. The effects of the financial crisis have been profound in Africa also. A 2012 UNAIDS report suggests that "countries across Africa have been widely impacted due to the combined effects of financial crisis with spikes in food and fuel prices”. (UNAIDS, 2012) Austerity through the lens of dependency was mentioned by Rowden and Velasco (2003), when, in criticising the approaches of "rich countries" in the wake of the Uruguayan Round they suggest that "the structural adjustment loan conditions of rigid fiscal austerity, wholesale trade liberalization, subsidy cuts and privatization are virtually the opposite of policies long used by rich countries in the course of their own successful industrial development.”
} 
to which Tong and Wei (2011) refer. This article highlights how increasing global dependence on capital, generated by multi - national corporations (MNCs), represents a crossroads in our hitherto understanding of financial systems. Suggestions in the literature point to the emergence of a new social class, overseeing MNCs. This TCC, described primarily by Robinson and Harris (2000) and Sklair (2001), has the sole purpose of profit accumulation. This, in an ever-shrinking globalised world, has implications for national development - economic, social and political. If economic development "goes global” a number of issues must be explored. First the implications for national economic, social and political policy must be considered, and second, how global financial development impacts on our understanding of the financial system and the role of governments within this system. Re-working dependency theory can assist this exploration. Adapting the concept to globalisation trends, a modified approach to dependency theory provides the tools for an alternative assessment of the global economy. Traditional dependency consisted of an underdeveloped periphery dependent on the core for prosperity, employment and trade, which, in itself, led to criticism (Leys, 1977). This article addresses these issues and considers the rise of other actors in the global capital landscape. Although not claiming to "solve" the inadequacies of the financial system, this article provides commentators with a better means to understand the problems facing legal, regulatory and policy reform.

\section{Dependency}

Dependency is a branch of development theory suggesting the existence of a core of wealthy “developed” states and a periphery of poorer "underdeveloped” states. To bolster and sustain economic growth in the "core", resources are extracted from the periphery. As the core develops, (through increased economic growth at the expense of the periphery's resources), the periphery underdevelops, (its resources have been given to the core), leading to a widening inequality gap. Work in this area includes Frank’s (1966, 1991) “underdevelopment” and Dos Santos’ (1973) “conditions of dependence”. Both can be adapted to a contemporary understanding of the world system via a modified approach to dependency, focussing specifically on the rise of the MNC and an increased focus on globalisation processes. 
The basic hypothesis of dependency is that "development and underdevelopment are partial, interdependent, structures of one global system” (O’Brien, 1975). Dos Santos (1973) considers it as “a conditioning situation in which the economies of one group of countries are conditioned by the development and expansions of others.” Dependent relationships exist "when some countries expand through self-impulsion, while others, being in a dependent position, can only expand as a reflection of the expansion of the dominant countries which may have positive or negative effects on their immediate development” (Dos Santos, 1973). "The relations of dependence, to which these countries are subjected, conform to a type of international and internal structure which leads to underdevelopment or, more precisely, to a dependent structure that deepens and aggravates the fundamental problems of their peoples” (Dos Santos, 1973).

Underdevelopment is the result of dependence. Dependency considers underdevelopment the result of unequal power relationships between core and peripheral economies (Valenzuela and Valenzuela, 1978). Developing countries are not poorer, or less developed, because they are behind in scientific discoveries, rather as a by-product of being coercively integrated into a system, (usually the European economic system), purely for the exploitation of natural resources and labour market (Dos Santos, 1973). The pressure to conform to a European, (and extended to the US), system was not necessarily the best option for these countries where infrastructure and human capital etc. were considerably different to those of most European nations. Examples in Latin America and Sub Saharan Africa, used at the time, prove Dos Santos' hypothesis about how economies developed, suggesting that development was conditioned by the requirements of the core. The pathway of development thinking in Africa, and how dependency theorists' incorporation of underdevelopment has helped frame policy approaches on the continent, is also interesting.

With Ghana today, the embedded nature of underdevelopment and dependency can be understood. Ghana is a former colony of the British Empire trading in gold and cocoa, (BBC, Profile). Infrastructure in Ghana was designed to ensure efficient transportation of natural resources to ports, highlighting how economic dependence led to underdevelopment of infrastructure beyond that required for exportation 
(Jedwab \& Moradi, 2012). From a social/cultural dependency aspect, laws of the British Empire were transplanted into Ghanaian law and failed to reflect customary laws, which had previously prevailed. Today, Ghana is still largely dependent on natural resources for trading purposes, and, despite independence, retains laws related to colonialisation. Ingrained underdevelopment remains with regard to infrastructure.

Post 1973, there were two distinct camps on African development thinking. Advocating dependency was the Organisation of African Unity (OCU) and the Economic Commission of Africa (ECA). Advocating neoliberalism was the World Bank and other financial institutions. Since the late 1990s, there has been a convergence in the thinking around development policy Africa. The bank adopted the Comprehensive Development Framework (CDF) which appears to recognise that donor led development is not necessarily effective, and African leaders began to espouse the benefits of neoliberalism, evidenced in the New Partnership for Africa’s Development (NEPAD) (Owusu, 2003).

This convergence represents an impasse. The World Bank could not explain how neoliberal policies were not developing. African leaders realised that securing investment would be more difficult if issues such as former exploitation continued to dominate development policies (Owusu, 2003). This convergence is still grounded in the statist approach and seems to miss key points of dependency. For instance, the World Bank could not explain the external issues under neoliberalism, and the African leaders could not explain the internal problems (Owusu, 2003). The fact that these are all part of one system, and that the underdevelopment of internal systems is interrelated with the exogenous issues, is not explored.

Dependency theory is useful today. It presents an alternative lens to view the global market system. Although the theory emerged prior to the expansion of MNCs and increased globalisation of the market, it still, subject to modifications, offers guidance on our understanding of financial crises. By proposing a modified dependency, this article considers how this might assist today. In drafting these modifications, it is necessary to look at the criticisms of the theory and see whether they can be resolved. 


\section{Problems and Criticisms of Dependency}

Criticisms of dependency are attributed to a few contentious issues within the theory. Each issue dilutes the strength of the paradigm as an effective tool of analysis. To modify the theory, these problems need to be synthesised into a coherent critique, resolved or mitigated.

Criticisms came from both the "right” and the Marxian inclined "left”. Leys (1996) suggests that the “right” failed to make an effort to understand the Marxist theories that inspired much of dependency's key concepts. The "left", highlight a number of weaknesses with the theory, which perhaps explain the failure of the theory to thrive in mainstream economic circles. Dependency theory was borne of the political climate at the time - there was the requirement for an alternative theory, contradicting mainstream diffusionist Rostovian thought and incorporating the historical aspect of individual nations (Rostow, 1960; Bernstein 1971). This gap, in tandem with the political climate, facilitated the theory’s conception and initial popularity. But, whereas this enabled dependency's conception, some suggest that the same global political climate prevented its long-term survival (Leys, 1996).

As a considerable amount of literature on dependency evolved when Bretton Woods was regulating the global system, it is understandable that, with market de-regulation, the theory would lack appeal and application. Returning to Tong and Wei (2011), the suggestion is that globalisation within the global markets has made national economies vulnerable to financial crisis. Extending this, the globalisation of the markets has impeded the independence of national markets at the least, and perhaps at most highlights the dependence of states on international market persuasions. Given that dependency emerged due to the transformation of the global system post World War II, whether dependency is still a relevant tool to understand global relationships can be questioned. The global system is constantly evolving. To still be relevant, dependency needs to evolve accordingly. Moving the theory, like the global system, beyond nation-state relations can help achieve this.

This most recent fiscal crisis has arguably affected “developed” countries more than "lesser developed” regions (Goodhart, 2008; Naudé, 2009). Critics may argue, again, that when the liquidity crisis recedes 
- the theory will fail. The current financial situation has shaken pre-existing beliefs relating to capitalism and effective governance (Stiglitz, 2010). This crisis enables a reassessment of the global economy and those systems that support it. Reformulating dependency may provide some answers around why perceived "strong" states are still affected by these types of shocks.

Criticism has been levelled at dependency as it emerged as a mirror image of modernisation (Leys, 1996). Despite this, the current market system may require a viable alternative to understand some issues highlighted by the on-going liquidity crisis.

Recurring in the literature is the failure to replace the core - periphery metaphor with "concrete typologies of centres and peripheries”(Leys, 1977). This trend manifests at a number of stages in the dependency literature (Booth, 1975). Such ambiguity is advantageous for reformulating dependency. With no concrete typologies of "core” and "periphery", modifying the theory and addressing this issue, could overcome the "impasse" associated with it. The next section, addressing these criticisms, develops a modified theory, providing an alternative lens for understanding financial crises.

\section{Modified Dependency}

Two insurmountable problems remained for critics. First, the failure to provide concrete typologies of core and periphery and second, dependency was concerned primarily with nation - state relations. These issues have solutions. Under traditional dependency, some states (usually colonising states) were considered "core" and others (usually colonised states) were considered peripheral. This was grounded in nation-state relations but is easily amended by altering the actors. If the typology for "core" was replaced with global capital (generated by MNCs) and the "periphery” becomes nation states (including the EU), the potential for the theory's evolution is realised. Also, application of the theory becomes almost universal, as those countries relying on MNCs to contribute to their economy (to differing extents) can be said, under this widened interpretation of dependency, to be dependent ${ }^{2}$.

\footnotetext{
${ }^{2}$ Differing extents is an ambiguous term. States previously cores (under the old terminology) and now peripheral - are 'less' peripheral than states previously dependent. The rationale for this comes from the idea
} 
This interpretation of dependency would also explain how even previously considered "core", “developed” regions have been affected. The next section of this article addresses the TCC. MNCs are agents of the TCC. Ultimately then, states are dependent on the TCC. This dependence is a dependence on investment for economic prosperity. Aside from the theoretical application of the theory, events over the last number of years, arising from the ubiquitous financial crisis, have provided the situation whereby the theory can be realised. A new, modified, dependency provides an alternative means to understand how globalisation has left society vulnerable to financial crises (Tong and Wei, 2011).

Global imbalances in equality are considered normal and the nature of capitalism (Leys, 1996). This is a struggle for modified dependency which presents as an advocate for equality. Society today is more inclined to subscribe to neoliberal structural adjustment type policy. As a unit of analysis, however, dependency may be instrumental in describing small open economies, former colonised regions and emerging nations. Including the manner in which growth indicators are assessed and financial crises interpreted can inspire a broader thought process on how future crises may be alleviated, if not averted. Mann (2005) suggests that, focus is on national inequality. Collective imbalance is limited -further evidence that thought patterns have not transcended the nation state. Re-education on the requirements of our global system is needed, particularly for legislators, regulators and policy makers.

Dependency appears concerned with the nation-state approach. Today, borders are becoming less distinct, and nations are becoming less important than entities that can cross borders (MNCs), suggesting there must be another way to approach the issue. Even today, terms such as co- (Mann, 2005), path- (Yeh, Lim and Vos, 2007; Bebchuk and Roe, 1999) and inter- (Kolb, 2011) dependency all prevail in the literature -again grounded in the national approach rather than a more global scale. These all suggest that within the global governance system there exists a dependence on the US model, reflected in the trends of emerging economies. New dependence goes beyond this. Reformulating the

that the previously 'core’ states have a stronger internal infrastructure (regulations). Previous peripheries are now more underdeveloped and their old limited autonomy has now become more comprised. 
theory will need to reconsider the transnational aspect of the global market system and by extension, dependency, by incorporating globalisation processes into changes to the paradigm.

This article refers to the role of the TCC and MNCs. Realigning actors within a new dependency will have a dual purpose. First, it will cement core peripheral typologies to capital (core) and regions (periphery). Second, and as a result of the first, it will resolve the preponderance of the literature on the nation state. Dos Santos' (1973) original conditions of dependence remain sound. Redefining the principal actors will overcome the core-periphery issue and the reliance on nation-state exchanges. The existence of a TCC has engendered academic discussion in recent times (Sklair, 1997, 2001, 2002; Robinson and Harris, 2000; Carroll and Carson, 2003). To this, another layer can be added - the idea that the TCC can be intertwined with dependency theory creating both an update of dependency and an alternative means of assessing the global economy. The borderless nature of the TCC means there is no real loyalty to a people, state or culture. Instead, capital accumulation and the drive to increase accumulations are the class' purpose.

As noted above, Dos Santos (1973) described dependency as "a conditioning situation in which the economies of one group are conditioned by the development and expansion of others," with relationships of dependency existing "when some countries expand through self-impulsion, while others, being in a dependent position can only expand as a reflection of the dominant countries which may have positive or negative effects on their immediate development”.

MNCs and the TCC have a role to play within a modified dependency framework. Considering them as major actors enables the theory to be adapted, incorporating globalisation processes. Reformulating Dos Santos' conditions is, as follows:

1. Modified Dependency theory is a conditioning situation in which the economies of countries and trading blocs are conditioned by the development and expansion of capital accumulation via MNCs.

2. This accumulation may manifest as investment within countries and trading blocs providing employment and services to the population. 
3. A relationship of modified dependence exists when MNCs (governed and directed by the TCC) expand through self-impulsion while countries and trading blocs can only expand as a reflection of the MNCs investment in their region, which may have a positive or negative effect on their immediate and long term development. This development may be economic, political or social.

Supplanting the idea of countries $\mathrm{v}$ countries to capital $\mathrm{v}$ countries gives the theory a global application. It answers criticisms of the old theory (nation state approach and concrete typologies). This TCC that governs MNCs is now the predominant "core”. Countries dependent on this core can only expand or develop, insofar as capital via the "core” allows them to (Jackman, 1982; Müller, 1973). Work by Dos Santos has been paramount to gaining an understanding of early perceptions of the MNC within the economy (and dependent structures). Addressing this below links it with the evolution of the MNC to the TCC - the implications and challenges that this presents are considered later.

\section{Modified Dependency's new Core}

\section{Origins of MNCs in Dependency}

Neoclassical economic thought believed that MNC investment promoted growth, providing external capital to substitute for, or supplement, local capital (Jackman, 1982). Under modernisation, foreign direct investment (FDI) apparently stimulates growth, introducing new technology into underdeveloped countries. Traditional dependency, considers FDI, via MNCs, the anathema of capitalist accumulation (O’Brien, 1975). To the MNC, internal structure of a country is irrelevant beyond its capacity to accumulate profit (Baran and Sweezy, 1966). Müller (1973) addresses how the MNC, under dependency, can, and does, exploit the national economy in its endeavour to accumulate profit.

\section{Impact on Economic, Political and Social Dependency}

Economic dependency contributes to underdevelopment of the periphery (Jackman, 1982). At the same time, the external orientation of the periphery's economics, encouraged by foreign investment, generates internal distortions and contradictions that retard growth. 
Politically, this has two implications (Jackman, 1982). First, it undermines the autonomy of the periphery. Through investing capital into the region, MNCs and international lending agencies become major, possibly dominant, forces in economic policy making, a position maintained by implicit threats of withdrawal from, and consequent loss of capital by, the host country (periphery). Second, it leads to the development of new class relations. This accelerates social inequality in the periphery; new groups emerge linked to the core, whilst the remainder of the periphery becomes increasingly marginal, both in economic and political terms (Jackman, 1982), reflecting relationships of political, social and economic dependency (Frank, 1974). Müller (1973) asserts that unless economic growth brings alleviation to those suffering most, growth is contributing not to development, but to the continued underdevelopment of the nation. Further, "just as MNCs are involved in the restructuring of the production section, so too they are a major force in restructuring the consumption sector” (Müller, 1973). This is a contradiction as the new structure of consumption is in "serious imbalance with the inadequate consumption capacity generated by the very production sector which the MNCs have so pivotally helped to create” and, therefore, MNCs themselves have negated any possibility for attaining new consumption goals by all but a small minority (Müller, 1973).

\section{MNCs as "core":}

Traditional dependency theorists recognised that MNCs may have a role within dependency. This was prophetic, given subsequent shifts in the global system. Analysis by Dos Santos, Müller and Frank on the MNC allows dependency theory's expansion beyond the nation state. The new core in a reformulated dependency is centred round the MNC and the TCC that controls it. Altering the actors in such a way facilitates globalising a hitherto national theoretical approach.

Today, "territorial boundaries of states no longer coincide with the extent of the limits of political authority over economy and society” (Strange, 1996; Stiglitz, 2003). The implications of transnational capital on the nation state must be considered within dependency today. Global capital, for instance, can be divided into two main areas; manufacturing/industrial capital and financial capital. Today, financial capital has developed into a profitable yet risky enterprise to the point that, "financial logistics 
dominate technology in a way that creates new policy problems and increases the risk of system stability.” (Feng et al, 2001). Nation states and relations with global actors have had to develop accordingly, incorporating changes in the "new" economy.

Globalisation is the most recent, (and on-going), manifestation of capitalism. Along with, and perhaps as a result of, these developments, has been the emergence of a new class, multinational in nature. Sklair (2001) describes this class as a Transnational Capitalist Class (TCC), based on corporations and in control of the processes of globalisation (Robinson and Harris, 2000). This article illustrates how transnational capital impacts upon, and beyond, the policies and legislation of the nation and supranational state. Any assessment, therefore, of the role of transnational capital needs to also consider how transnational capital is represented: i.e. through global actors and institutions that operate at national and supranational levels. The TCC is described as "that segment of the world bourgeoisie that represents transnational capital, the owners of the leading worldwide production as embodied in the transnational corporations and private financial institutions” (Robinson and Harris, 2000). Sklair (2001) defines the class as the "identifiable actors working through institutions they own and or control" that drive globalisation”. ${ }^{3}$

This section accepts the premise of a modified theory of dependence focused on the new "core". Literature has not considered MNCs as "cores" within the dependency framework. As noted above, early theorists recognised the potential role of MNCs within the global market system. Considering capital generated by MNCs as "core”, the section also looked at how this realignment of actors would have an impact on economic, political and social development. These three themes underpinned the early work of Frank and are developed below, with focus on the role of underdevelopment under new dependency.

\footnotetext{
${ }^{3}$ Literature on the TCC, or an international capitalist class has been emerging since the 1960s. See Hymer, The Multinational Corporation: A Radical Approach, (Cambridge University Press 1979) and Goldfrank, 'Who rules the world? Class formation at the international level,' (1977) 1 (2) Quarterly Journal of Ideology, 32). They discuss that the "capitalist class increasingly...see their future in the further growth of a world market"(Hymer) and the fact that the growth of multinational enterprise has spawned a new corporate elite. (GoldFrank)
} 


\section{The Development of Underdevelopment and the Underdevelopment of Development 2.0}

States are no longer masters of the markets (Strange, 1996). Today, markets are the masters of the states, "and the declining authority of states is reflected in a growing infusion of authority to other institutions and associations and to local and regional bodies and in a growing asymmetry between the larger states with structural power and the weaker ones without it” (Strange, 1996). Far from removing inequalities therefore, a more global system suggests that problems go beyond the surface. Challenges and problems identified by traditional dependency still persist today.

Reflecting on the literature, and incorporating globalisation processes into the debate, the challenges for dependent and underdeveloped regions can be explained in a more succinct, albeit simplistic, manner. The parameters of dependency, at its most basic, can be interpreted using the following scenario that deploys a simple cost/ benefit analysis.

\section{Scenario 1}

A company wants to make a profit on a product (P).

Two competing groups of equal training and competence wish to provide Labour (L).

For group one, there are additional requirements.

Group 1 require that in exchange for Labour (L) a higher Wage (W) is paid with Benefits (B)

i.e. $\mathrm{L}=\mathrm{Wn}+\mathrm{B}$.

Group 2 want a wage less than the higher wage demanded by Group 1.

i.e. $\mathrm{L}=\mathrm{W}<\mathrm{Wn}$.

Unsurprisingly, Group 2 receives the contract.

This is simplistic and does not take into account, overheads, international labour obligations etc. If you expand this analysis to a regional level using old cores (Co) and old peripheries (Pe) the concept of underdevelopment is easier understood.

\section{Scenario 2}

A company wishes to accumulate profit by investing in a region (Pr). 
In exchange, the company will provide employment (L).

In the former "core” country the cost of Labour (L) includes; a higher Wage (Wn), Benefits (Bn) and compliance with national regulations (R) on a number of issues. The company needs to factor this in.

Cost (C).

$\operatorname{Pr}=\mathrm{C}-(\mathrm{Wn}+\mathrm{Bn}+\mathrm{Rn})$

For the former periphery, training may be required, and limited infrastructure exists. There are less benefits and regulations. Here, the cost of Labour is $\mathrm{W}<\mathrm{Wn}$ plus $\mathrm{B}<\mathrm{Bn}$ plus limited regulations (vary depending on the region) $\mathrm{R}<\mathrm{Rn}$. Also, the cost of training ( $\mathrm{T}$ ) and improving the infrastructure (I) must be considered.

For the Peripheral region,

$\mathrm{Pr}=\mathrm{C}-(\mathrm{W}<\mathrm{Wn}+\mathrm{B}<\mathrm{Bn}+\mathrm{R}<\mathrm{Rn}+\mathrm{T}+\mathrm{I})$

If

$\operatorname{Pr}=\mathrm{C}-(\mathrm{Wn}+\mathrm{Bn}+\mathrm{Rn})<\mathrm{Pr}=\mathrm{C}-((\mathrm{W}<\mathrm{Wn})+(\mathrm{B}<\mathrm{Bn})+(\mathrm{R}<\mathrm{Rn})+\mathrm{T}+\mathrm{I})$

- the former Core will attract investment.

If, $\mathrm{Pr}=\mathrm{C}-(\mathrm{Wn}+\mathrm{Bn}+\mathrm{Rn})>\mathrm{Pr}=\mathrm{C}-((\mathrm{W}<\mathrm{Wn})+(\mathrm{B}<\mathrm{Bn})+(\mathrm{R}<\mathrm{Rn})+\mathrm{T}+\mathrm{I})$

- the former Periphery will attract investment.

Whereas the core may still attract investment - even with a stronger regulatory infrastructure and greater benefits to employees etc., this can be withdrawn especially once the peripheral region becomes a cheaper investment. This will prevent regulatory advancement in the former core as they strive to compete. For the former periphery, development was already underdeveloped. Should they attract investment, they are doing so because there are fewer regulations to comply with, cheaper wages and 
fewer benefits to employees. This inhibits the prospect of law, regulatory or policy reform seeking to introduce higher wages, benefits and regulations as, to do so, would make their region less attractive. Therefore, economic dependence on capital has an impact on political and social dependence (Frank 1966, 1991). Legislation is not introduced if it could result in capital relocating elsewhere, equating to political dependence. Benefits for employees, better regulations etc are limited in their introduction for the same reason, leading to social dependence. This illustration is crude, failing to recognise exogenous factors but helps illustrate the point. The new core has fewer loyalties than the old core. The former core consisted of nation states, which had some loyalties to former colonies. This new core only has loyalties to capital and capital accumulation, ensuring a much more detrimental effect on the global economy, further expediting the underdevelopment of development. For Africa, where most countries would have been understood as classic "peripheral” regions under traditional dependency, the challenge is developing the region, enhancing existing laws and regulations governing labour rights, human rights, sustainable development, yet not alienating capital investment from a costs perspective.

As capital has evolved, so too has the quest for capital. Where once states competed for territory to assert their power, today this is replaced by competition for investment, market shares and natural resource territory (Stopford and Strange, 1991). Bargaining power as the new military power would mean that the state with the most investment would theoretically be the most powerful state. Old alliances of national capital have mutated into a transnational bourgeoisie and today, this class is the one with hegemonic capabilities (Strange, 1996). What distinguishes the TCC from these local and national capitalists is its involvement in globalised production and manages "globalised circuits of accumulation that give it an objective class existence and identity...above any local territories and politics” (Strange, 1996).

Initiated by Dos Santos and Frank, dependency theory and the role of the MNC attracted some limited commentary in the 1970s. In identifying the further globalisation of the market system since the 1970s, to the MNCs being a component of a wider class - the TCC, this section has precipitated analysis of 
the financial crisis via dependency (albeit a modified dependency) below which rationalises the crisis and explains its inevitability.

\section{Africa, New Dependency, Financial Crisis and CSR - Challenges for the Future}

From the birth of capitalism, there has always been dependency and, as an extension, there have always been dependent relationships. Dependency can help explain the emergence of crisis and future implications (Castells and Laserna, 1989). Earlier this article referred to Dos Santos' (1973) conditioning situations. Intertwining social, political and economic dependence, ideas of dependence embedded into national infrastructure can be understood (Müller, 1973).

Dependency means that when new forms of dependence arise (such as dependence on foreign capital), "new" dependence is being imposed on countries and regions that were dependent to begin with (albeit a different form of dependence), further constraining their capacity to react freely to new dependence and further embedding the underdevelopment of development. If all countries had started as equals this would be moot. Incorporating an historical analysis, colonies effectively coerced into a European style economic capitalist system were put at a disadvantage. Capitalism is orientated towards inequalities, some regions succeeding at the expense of others. Colonies were always (apart from the US), peripheral - dependent on the core for their own development.

Today there is a crossroads of competing dependencies. Dominant actors in the global system remained a constant until the last number of years. New dependency and its main actors (MNCs \& TCC) have been driving the restructuring of the financial and market system from an economic point of view. Old actors remain, but are now competing with the new actors for dominance. As they are competing with each other, there are now old cores in the periphery today and former peripheries, which are now more peripheral than before. This has implications for economic, political and social development, highlighted above. The interconnectedness of political, economic and social development was paramount in Frank’s (1966, 1991) work with Jackman (1982), reflecting on the relationship between the three, and the dependency framework suggesting that economic dependence meant governments 
were afraid of losing capital (political dependence) by legislating on issues that may be beneficial to the people, but acting to the detriment of capital (social dependence) $)^{4}$.

Attempts to resolve the financial crisis have been/are being carried out via austerity policies at interfederal and national levels. Today new, (almost global), core actors are restructuring the economy but are regulated by old, (national or federal), dominant actors. Freedom to respond to the new core is curtailed - limiting the effectiveness of crises response and further recognising Frank’s $(1966,1991)$ development of underdevelopment and the underdevelopment of development. This transition period highlights how difficult it is, and how likely this crisis was to occur.

This special edition focuses on Africa. Africa's past and legacy of colonisation mean that as a continent, it falls within the traditional paradigm of dependency. Under this theory, many of these former colonies are also former peripheries and therefore in the most tenuous position in the global market system as indicated above.

The challenge for national governments within Africa will be attracting investment from the new core (MNCs) whilst ensuring that investment contributes holistically to their economic, social and cultural development (Frank, 1966, 1991). This can be achieved through developing regulations, laws and policies to ensure that human rights, equality and labour standards are being observed, in line with the Northern hemisphere. Whether this can be done in - or inter-dependently is, as yet, untested. Potentially, utilising corporate CSR policies such as Corporate Community Involvement could provide the vehicle by which to develop state level laws, regulations and policies independent of economic

\footnotetext{
${ }^{4}$ This argument can be seen the criticisms of Obamacare. Some refer to Hayek using "competition" as a means of criticising it. Hayek was concerned about economic planning (and extension regulation) as it impacted on the state's capacity to compete. He believed that one person or group of persons should not be in control as it would be akin to a dictator looking at future planning. Of paramount importance was individual freedom followed by competition. At all costs, society wished to avoid collectivism. But in using this argument, not only are critics highlighting the "dependence" of states - but also the inequality of capitalism. Condemning the idea that everyone, regardless of underlying condition is entitled to healthcare - such criticisms illustrate how society accepts inequality as a norm and indeed fear of becoming "less competitive" overrides compassion. (Hayek, 1944, 2001). Whereas it might be the case that no one person, or group of persons should be in control, the mutation of capitalism to the MNC and by extension to the TCC has meant that a collective group - with the sole aim of capital accumulation - have a dictatorship on the global economy. This economic wealth has implications on social and political dependence. A similar argument is put forward in response to Dodd Franks Act but here, it is more that some institutions have more power than others.
} 
investment. Viewing government as external stakeholders may ensure that governance infrastructure can, at least, be developed. Dependency's legacy, and the advent of a more ingrained dependence, will make this engagement unequal, with hurdles difficult to overcome. New dependence, and the power of the MNC has been noted in communications from international organisations, for example the "Ruggie" Principles (2011) which, by stating that “[t]he issue of business and human rights became permanently impacted on the global policy agenda in the 1990s, reflecting the dramatic worldwide expansion of the private sector at the time, coupled with a corresponding rise in transnational economic activity" recognises another player in the global capitalist hierarchy. It is concerning that national governments are facing the trial of engaging with MNCs to attract investment, overcoming a legacy of peripheral underdevelopment, law, regulatory and policy development, all in the climate of a global financial crisis.

\section{Conclusions}

The recent financial crisis highlighted shifts in our market system. These shifts (the nature of trade, the transition from manufacturing to finance capital and global exchanges), provide the opportunity to reevaluate our understanding of the global system.

This article looked at dependency theory. Dependency addresses relationships within the global system, founded on the idea that there are two main actors. These actors, described by Frank and Dos Santos, are the "core" and "periphery". States fell into one or other of these groups. Core states were considered wealthy developed states (usually colonisers). They maintained this wealth and development by extracting resources from the less developed/underdeveloped periphery (usually colonies). The periphery's development was therefore conditioned by the core’s development.

Although this theory fell into disrepute with the collapse of Bretton Woods, it still offers an alternative assessment of the market system at this transnational stage of crisis, response and global development. Modifications are required to incorporate the rise of MNCs and the increased globalisation of the markets. Retaining the language of Dos Santos, and particularly his conditions of dependence, ensures that dependency today is still focussed on the relationship between core and periphery. Today, the actors have changed. The 'core' today is the MNC, capital investment, and the TCC, which oversees 
its activities. The 'periphery' are states, all states and trading blocs within the global economy. Dependent relationships exist in this modified dependency when MNCs (governed and directed by the TCC) expand through self-impulsion while countries and trading blocs only expand as a reflection of MNC investment in their region, which may have a positive or negative effect on their immediate and long term development. This development may be economic, political or social.

In many ways, the problems that existed in the 'old' system still prevail within the new. The fear of alienating capital overrides desires to innovate in terms of law, regulatory or policy reform. Under the old system, some loyalties may have existed between states; today, the new system would suggest that with capital as the core, loyalty is to capital and capital accumulation. Cultures become less relevant. The future holds some hope with the global shift towards CSR practice. Whether this can be achieved in an independent manner remains unclear.

Dependency exists, a side-effect of capitalism, a side-effect of the winner takes all nature of financial supremacy. The face of dependency today has changed, although the basic premise remains sound. Capital generated by entities with no loyalty to a class, culture or race is now the core. All states and regions are, to varying extents, dependent on this core for economic prosperity and socio-political sustainability and development. However, old dependency is still in place - as well as the embedded underdevelopment arising from "old" dependence. This curtails the ability of the old core and further constrains the autonomy of the old periphery to answer/compete as an equal with the "new" core. With both new and old dependency still prevailing in the world system, the financial crisis of 2007-2008 was inevitable. Whereas the new core is able to advance and further augment its position by manipulating the globalisation processes, the entities/national infrastructures that regulate, legislate on the activities of the core have become either curtailed in their effectiveness to regulate (old core) or further embedded in underdevelopment (old periphery). The conditions of underdevelopment have meant that the new periphery is limited - it is unable to catch up. Whereas the core can transcend national borders the periphery currently cannot - limiting the effectiveness of regulation and making financial crises and resultant instability inevitable. With the core winning the survival of the fittest, peripheral regions are 
competing amongst themselves in the race to the bottom, widening the burden of inequality and developing underdevelopment. The winner: capital. 


\section{Reference List}

\section{Cases}

National Federation of Independent Business v Sebelius, 567 US_(2012)).

\section{Legislation}

Wall Street Reform and Consumer Protection Act 2010 (Pub. L. 111-203, HR. 4173)

The Patient Protection and Affordable Care Act (PPACA)

\section{Articles}

Bebchuk, L.A. and Roe, M. (1999), “A theory of path dependence in corporate ownership and governance”, Stanford Law Review, Vol. 52 No. 1, pp. 127 - 170.

Bernstein, H. (1971), “Modernisation theory and the sociological study of development”, Journal of Development Studies, Vol. 7 No. 2, pp.141-160.

Carroll, W. and Carson, C. (2003), "The network of global corporations and elite policy groups: a structure for transnational capitalist class formations”, Global Networks, Vol. 3 No. 1, pp. 29 -57.

Castells, M. and Laserna, R. (1989), “The new dependency; Technological change and socio-economic restructuring in Latin America”, Sociological Forum, Special Issue: Comparative National Development: Theory and Facts for the 1990s, Vol. 4 No. 4, pp. 535 -560.

Dos Santos, T. (1970), “The Structure of Dependence”, American Economic Review, Vol. 60 No. 2, pp. 231 - 236.

Feng, H. Froud, J. Johal, S. Haslan, C. and Williams, K. (2001), “A New Business Model? The Capital Market and the New Economy”, Economy and Society, Vol. 30 No. 4, pp. 467 -503

Frank, A.G. (1974) "Dependence is dead, long live dependence and the class struggle: An answer to critics”, Latin American Perspectives, Vol. 1 No. 1, pp. 87 - 106.

Goldfrank, W. (1977), “Who rules the world? Class formation at the international level”, Quarterly Journal of Ideology, Vol. 1 No. 2, pp. 32-37.

Goodhart, C.A.E. (2008), “The regulatory response to the financial crisis”, Journal of Financial Stability, Vol. 4 No. 4, pp. 351- 358.

Jackman, R. (1982), "Dependence on foreign investment and economic growth in the third world”, World Politics, Vol. 34 No. 2, pp. 175-196.

Leys, C. (1977), “Underdevelopment and Dependency: Critical Notes”, Journal of Contemporary Asia, Vol. 7 No. 1, pp. 92-107.

Mann, C. (2005), "Breaking up is hard to do: Global co-dependency, collective action and the challenges of global adjustment”, CESifo Forum, Vol. 6 No. 1, pp. 16 -24.

Owusu, F. (2003), "Pragmatism and the gradual shift from dependency to neoliberalism: The World Bank, African leaders and development policy in Africa”, World Development, Vol. 31 No. 10, pp. 1655 - 1672.

Robinson, W. and Harris, J. (2000), "Towards a Global Ruling Class? Globalisation and the Transnational Capitalist Class”, Science and Society, Vol. 64 No. 1, pp. 11 -54.

Rowden, R. and Velasco, A. (2003), “Dependency Lives,” Foreign Policy, No. 136, pp.16-16. 
Sklair, L. (1997), “Social Movements for Global Capitalism: The Transnational Capitalist Class in action”, Review of International Political Economy, Vol. 4 No. 3, pp. 514 -538.

Sklair, L. (2002), “The Transnational Capitalist Class and Global Politics: Deconstructing the Corporate State Connection”, International Political Science Review, Vol. 23 No. 2, pp. 159- 174.

Tong, H. and Wei, S. (2011), “The composition matters; Capital inflows and liquidity crunch during a global economic crisis”, Review of Financial Studies, Vol. 24 No. 6, pp. 2023-2052.

Valenzuela, J.S. and Valenzuela, A. (1978), "Modernization and Dependency: Alternative perspectives in the study of Latin American underdevelopment”, Comparative Politics, Vol. 10 No. 4, pp. 535- 557.

Yeh, A. Lim, S. and Vos, E. (2007), "Path Dependence or Convergence: The Evolution of Corporate Ownership around the world”, Review of Law and Economics, Vol. 3 No. 2, pp. 517-551.

\section{Books}

Baran, P. (1957), The Political Economy of Growth, Monthly Review Press, New York.

Baran, P. and Sweezy, P. (1966), Monopoly capital: An essay on the American economic and social order, Monthly Review Press, New York.

Frank, A.G. (1967), Capitalism and Underdevelopment in Latin America, Monthly Review Press, New York.

Frank, A.G. (1966), The Development of Underdevelopment, Monthly Review Press, New York.

Frank, A.G. (1991), The Underdevelopment of Development, Bethany Books, Stockholm.

Hayek, F. (1944, 2001), The Road to Serfdom, $2^{\text {nd }}$ Edition, Routlege, London.

Hymer, S. (1979), The Multinational Corporation: A Radical Approach, Cambridge University Press, Cambridge.

Kolb, R. (ed) (2011), Financial Contagion: The Viral Threat to the Wealth of Nations, John Wiley \& Sons, New Jersey.

Leys, C. (1996), The Rise and Fall of Development Theory, James Currey Ltd, London.

Rostow, W.W. (1960), The Stages of Growth: A non-Communist Manifesto, Cambridge University Press, Cambridge.

Scott, J. (1997), Corporate Business and the Capitalist Classes, Oxford University Press, Oxford.

Sethi, P. and Williams, O. (2000), Economic Imperatives and Ethical Values in Global Business: The South African Experience and International Codes today, Kluwer Publishers, Boston

Sklair, L. (2001), The Transnational Capital Class, Blackwell Publishing, Oxford.

Stopford, J. and Strange, S. (1991), Rival States, rival firms: Competition for world market shares, Cambridge University Press, Cambridge

Strange, S. (1996), The Retreat of the State: the Diffusion of Power in the World Economy, Cambridge University Press, Cambridge.

\section{Chapters}


Booth, D. (1975), “Andre Gunder Frank: An introduction and an appreciation”, in Oxaal, I, T Barnett, and D

Booth, (eds) Beyond the Sociology of Development. Routledge and Kegan Paul, London pp. 50 - 86.

Dos Santos, T. (1973), “The crisis of development theory and the problem of dependence in Latin America”, in Bernstein, H. (ed), Underdevelopment and Development, Penguin, Harmondsworth pp. 57-80.

O’Brien, P. (1075), “A critique of Latin American theories of dependence”, in Oxaal, I., T. Barnett, and D. Booth, (eds) Beyond the Sociology of Development. Routledge and Kegan Paul, London pp. 7 - 49.

Stiglitz, J. (2003), “Toward a new paradigm of development”, in Dunning, J. (ed), Making globalisation good, Oxford University Press, Oxford. 76-108

\section{Discussion and Working Papers}

Naudé, W. (2009), “The Financial Crisis of 2008 and developing countries”, Working Paper [2009/01] UNUWIDER Discussion paper, Helsinki, 2009.

\section{News Clippings}

BBC News: Ghana Country Profile www.bbc.co.uk/news/world-africa-13433790 Sourced on the 5th December 2012.

Stiglitz, J. (2010), “Needed: A New Economic Paradigm”, Financial Times, 19 August http://www.ft.com/cms/s/0/d5108f90-abc2-11df-9f02-00144feabdc0.html\#axzz1DIPiaBWW Sourced on 07-022011

\section{Reports}

Global Reporting Initiative http://www.globalreporting.org/Home

Global Sullivan Principles of Social Responsibility http://www.thesullivanfoundation.org/gsp/default.asp

Principles for Global Corporate Responsibility Benchmark http://www.bench-- marks.org/

Social Accountability 8000 (SA8000) http://www.sa-- intl.org/

UNAIDS, 2012, Impact of the global economic crisis on women, girls and gender equality, www.unaids.or/media

United Nations Global Compact http://www.unglobalcompact.org/

United Nations Guiding Principles on Business and Human Rights http://www.business--

humanrights.org/media/documents/ruggie/ruggie-- guiding-- principles-- 21-- mar-- 2011.pdf

\section{Unpublished Conference Proceedings}

Jedwab, R. and Moradi, A. (2012), “Colonial Investments and Long Term Development in Africa: Evidence from Ghanaian railroads”, Paper presented at a number of conferences and seminars including Oxford, Bocconi, LSE and George Washington University. Available at Home.gwu.edu/ jedwab/Jedwab_Moradi_Nov_2012.pdf (Accessed 5th December 2012). 
